\title{
СУЧАСНІ ПІДХОДИ ДО ВИВЧЕННЯ ФОТОТЕРАПІЇ У НОВОНАРОДЖЕНИХ
}

Т. І. Шевцова

\author{
Національниймедичний університет імені О. О. Богомольия
}

\section{MODERN APPROACHES TO STUDYING OF PHOTOTHERAPY IN NEWBORNS}

\section{T. I. Shevtsova}

\author{
National Medical University by O. O. Bohomolets
}

\begin{abstract}
Система підготовки сімейних лікарів передбачає підвищення якості освіти шляхом впровадження навчальних програм, що відповідають сучасному рівню розвитку науки згідно з основними критеріями професійної компетентності. Фототерапія є найбільш ефективним і широко використовуваним методом консервативного лікування у новонароджених 3 неонатальною жовтяницею. У статті розглянута доцільність фототерапії в лікуванні неонатальних жовтяниць, дана характеристика основних методів фототерапії, сучасні рекомендації щодо раціонального використання.
\end{abstract}

The system of training for family physicians implies increasing the quality of education through the implementation of educational programs that meet the current level of development of science in accordance with the basic criteria of professional competence. Phototherapy is the most effective and widely used method of conservative treatment of infants with neonatal jaundice. The article discusses the appropriateness of phototherapy for the treatment of neonatal jaundice, the characteristics of the main methods of phototherapy, and contemporary recommendations for the rational use.

Вступ. Переддипломна підготовка майбутніх сімейних лікарів з неонатології повинна бути проблемно і практично орієнтованою з акцентом на оволодіння професійними вміннями ранньої діагностики патології, надання невідкладної допомоги, терапії та реабілітації цих дітей у подальшому.

Під час навчання на 5 i 6 курсах студенти за спеціальністю "Лікувальна справа" докладно вивчають гемолітичну хворобу новонароджених, особлива увагаприділясться диференційній діагностиці неонатальних жовтяниць (НЖ). Під час занять студенти знайомляться з сучасними стандартами ведення новонароджених дітей з жовтяницею, відповідними наказами МОЗ України, що регламентують надання спеціалізованої неонатальної допомоги. Вважаємо, що при вивченні неонатальних жовтяниць вкрай важливо приділити увагу фототерапії як найбільш часто використовуваному методу консервативного лікування новонароджених з НЖ, які мають велику медикосоціальну значимість, враховуючи їх поширеність і частоту інвалідизації.

Неонатальна жовтяниця (НЖ) є проблемою, що часто зустрічається у новонароджених. Враховуючи значну актуальність проблеми, необхідно продовжу-

(C) Т. І. Шевцова вати оптимізацію ведення новонароджених з неонатальною жовтяницею для поліпшення прогнозу захворювання. За останні десятиліття істотно змінювалися погляди на тактику ведення дітей з НЖ, тому часто можна зустріти розбіжності в поглядах на цю проблему у практичних лікарів-неонатологів. Метою нашої роботи став аналіз сучасних підходів до проведення фототерапії у новонароджених дітей.

Основна частина. Згідно з сучасними уявленнями, НЖ - це поява видимого жовтого забарвлення шкіри, склер та слизових оболонок дитини, що відзначається у доношених при рівні білірубіну понад 85 мкмоль/л, у недоношених - більше 120 мкмоль/л. У європейській популяції НЖ зустрічається у 60 \% доношених і 80 \% недоношених дітей на 1-му тижні життя. Найчастіше відзначається фізіологічна жовтяниця, на частку якої припадає до 60-70 \% усіх жовтяниць $[1,6]$.

В Україні тактика ведення НЖ закріплена в наказі МО3 України від 27.04.2006 р. № 255 “Про затвердження клінічного протоколу надання неонатологічної допомоги дітям “Жовтяниця новонароджених". На сьогодні єдиними методами лікування НЖ, рекомендованими українськими та зарубіжними протоколами, $\epsilon$ фототерапія і замінне переливання крові (ЗПК) [4]. 
Фототерапія є найбільш ефективним і широко використовуваним методом консервативного лікування у новонароджених з неонатальною жовтяницею. Цей метод вперше був застосований Кремером 1958 року у Великобританії, але широке застосування отримав тільки з 1968 року, коли Lacey (1972) показав його ефективність у лікуванні некон'югованої гіпербілірубінемії $[3,15]$.

В основі фототерапії лежить здатність молекул непрямого білірубіну (НБ) під впливом світлової енергії змінювати хімічну структуру і відповідно фізико-хімічні властивості. Використовуються пристрої фототерапії, які випромінюють світло з довжиною хвилі близько 450 нм. Світло викликає в шкірі фотохімічну реакцію, при якій НБ перетворюється на фотобілірубін, що екскретується клітинами печінки в жовч. Крім того, в результаті реакції фотооксидації відбувається утворення білівердину, дипіролів або монопіролів - водорозчинних продуктів білірубіну, що виводяться 3 організму з сечею. I нарешті, під впливом фототерапії відбуваються структурні зміни молекули НБ (внутрішньомолекулярне утворення зв'язків між пірольними кільцями), що ведуть до утворення вже іншого нетоксичного незворотного ізомера - люмірубіну (фотобілірубіну, циклобілірубіну, люмібілірубіну), тривалість напіввиведення якого 3 крові 2 год, тоді як перераховані вище ізомери виводяться з організму протягом $12-$ 15 год. Основним шляхом елімінації НБ з організму в процесі фототерапії є утворення люмібілірубіну [2, 5].

Фототерапія проводиться за допомогою стандартних установок для фототерапії. Доступні кілька різних джерел світла:

1. Флюоресцентні лампи. Найбільш ефективні лампи блакитного і “спеціального синього” світла. Лампи денного, зеленого та інших кольорів світла теж ефективні, але переважно терапевтичний вплив на організм забезпечується блакитною частиною світла. Флюоресцентна лампа може встановлюватися на відстані 20 см від хворого. Потрібно враховувати, що інтенсивність випромінювання змінюється обернено пропорційно до квадратного кореня відстані. Це означає, що переміщення лампи на відстань, вдвічі більшу від рекомендованої, призведе до зменшення інтенсивності опромінення на 1/4 від потрібної величини.

2. “Плямиста" фототерапія з використанням галогенових джерел світла (кварцовий галоген). Галогенові лампи виробляють більше тепла, ніж лампи денного і блакитного флюоресцентного світла. Галогенові лампи встановлюють не ближче 50 см від дитини. У разі використання декількох галогенових ламп слід упевнитися, що ділянки світла не перекриваються, оскільки ці зони надмірно нагріваються і можуть виникнути опіки.

3. Волоконно-оптична фототерапія, яка генерує мало тепла і може бути поміщена ближче до немовляти (фотоковдра, матрацик або пелюшка). Вона показала себе менш ефективною, ніж традиційна терапія, але більш ефективною, ніж повна відсутність терапії. Частіше використовується для недоношених дітей у зв'язку з недостатньою площею випромінювання через невеликі розміри матрацика. Використання волоконно-оптичних ламп протипоказано у дітей з порушеннями гемодинаміки, набряками або екстремально низькою масою тіла.

4. "Інтенсивна" фототерапія з використанням кількох джерел світла, що забезпечує більшу потужність випромінювання [5, 18].

Своєчасна і правильно проведена ФТ не усуває причину жовтяниці, але знижує необхідність в ЗПК до 4 \% і зменшує ймовірність розвитку ускладнень НЖ. Фототерапію застосовують тільки після проведення діагностичного обстеження [2].

Фототерапію починають негайно при появі симптомів “небезпечної” жовтяниці, не чекаючи результату загального білірубіну сироватки (ЗБС) крові (табл. 1).

Одночасно проводять аналіз крові для визначення ЗБС крові. Необхідно враховувати такі фактори ризику, як гіпоксія, ацидоз, гемоліз, гіпоглікемія, гіпоальбумінемія, незрілість. Питання про продовження чи завершення ФТ вирішують після отримання результатів ЗБС згідно з діаграмами (рис. 1, 2).

Таблиця 1. Критерії “небезпечноі” жовтяниці (ВОO3, 2003, ISBN 924154622 0)

\begin{tabular}{|l|l|}
\hline \multicolumn{1}{|c|}{ Вік дитини (години) } & \multicolumn{1}{|c|}{ Локалізація жовтяниці } \\
\hline 24 & Будь-яка \\
\hline $24-48$ & Кінцівки \\
\hline$>48$ & Стопи, долоні \\
\hline
\end{tabular}




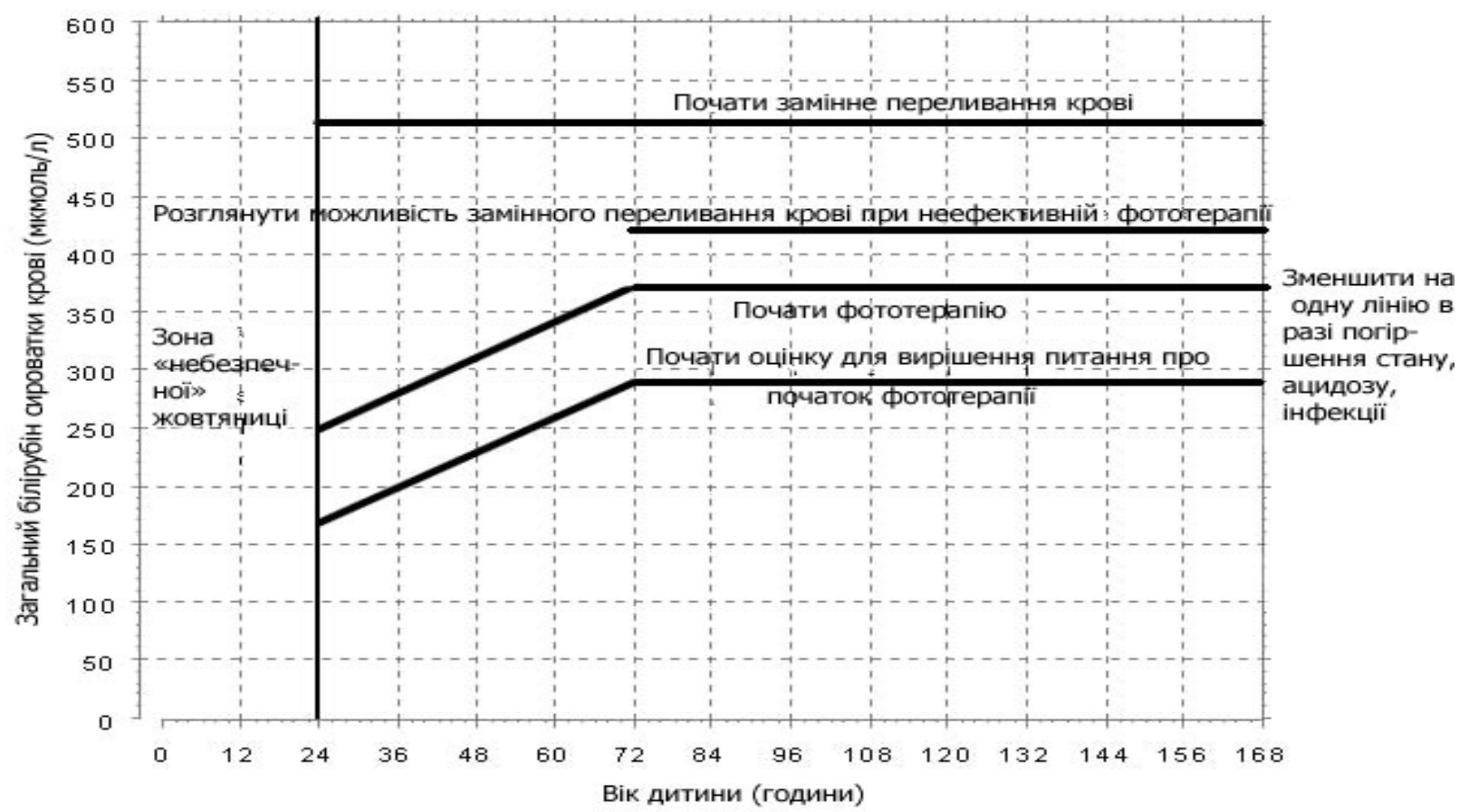

Рис. 1. Показання до фототерапії та замінного переливання крові у доношеного новонародженого без ознак гемолітичної хвороби.

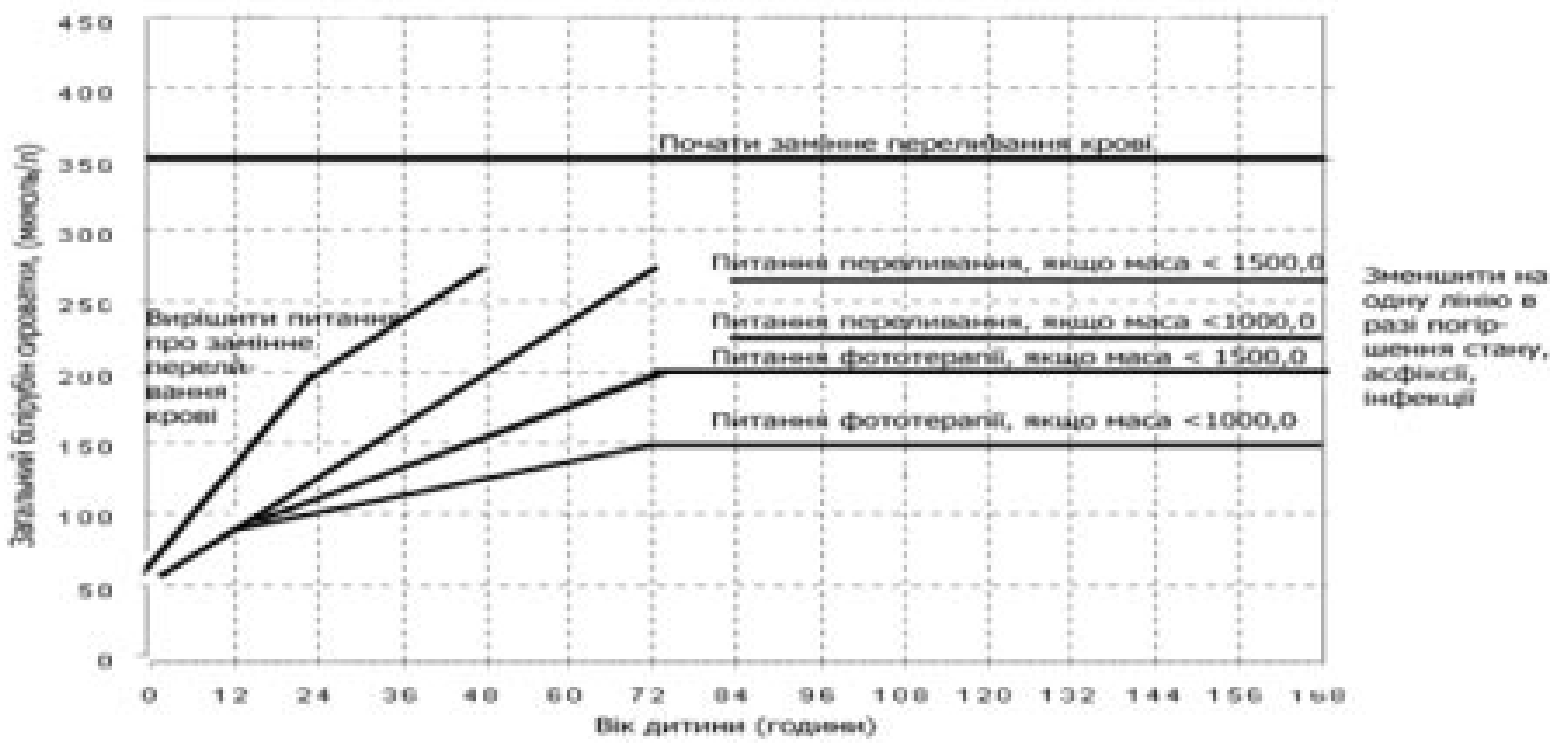

Рис. 2. Показання до фототерапії та замінного переливання крові у новонародженої дитини з ознаками гемолітичної хвороби або в недоношеного новонародженого.

У недоношених дітей i дітей з ознаками гемолітичної хвороби рівень ЗБС, необхідний для початку терапії, істотно нижчий $[13,14]$.

У різних країнах ці цифри дещо варіюють. Так, згідно з клінічними рекомендаціями Великобританії, фототерапію у новонародженого в терміні гестації 38 тижнів і більше слід починати при рівні ЗБС більше 350 мкмоль/л $[15,16]$. За рекомендаціями США фототерапію у новонародженого без факторів ризику в терміні гестації 38 тижнів і більше слід починати при рівні ЗБС, що перевищує 359 мкмоль/л [19].

Згідно з С. Езутачану рекомендовані наступні показання для використання фототерапії у дітей з малою масою тіла в період новонародженості (табл. 2) [5].

У Медичному центрі університету штату Кентукі на допомогу неонатологам була розроблена таблиця для визначення показань до фототерапії у новонароджених перших семи днів життя (табл. 3). 
Таблиця 2. Показання для використання фототерапії у новонароджених

\begin{tabular}{|l|l|}
\hline \multicolumn{1}{|c|}{ Маса тіла } & \multicolumn{1}{c|}{ Показання до фототерапії } \\
\hline$<1500$ & $\begin{array}{l}\text { Починати в перші 24 години життя (особливо якщо маса тіла }<1000, \epsilon \text { несумісність } \\
\text { по еритроцитарних антигенах або гематоми) незалежно від концентрації білірубіну в } \\
\text { сироватці }\end{array}$ \\
\hline $1501-1999$ & Без гемолізу - при 171 мкмоль/л. 3 гемолізом - при 136,8 мкмоль/л \\
\hline $2001-2499$ & Без гемолізу - при 205,2 мкмоль/л. 3 гемолізом - при 171 мкмоль/л \\
\hline
\end{tabular}

Таблиця 3. Визначення показань до фототерапії (показники білірубіну в мкмоль/л)

\begin{tabular}{|c|c|c|c|c|c|c|c|}
\hline \multirow{2}{*}{$\begin{array}{c}\text { Маса тіла } \\
\text { при народженні, г }\end{array}$} & \multicolumn{7}{|c|}{ Вік (дні) } \\
\cline { 2 - 8 } & 1 & 2 & 3 & 4 & 5 & 6 & 7 \\
\hline Менше 1000 & 51,3 & 51 & 51 & 86 & 86 & 118 & 118 \\
\hline $1000-1249$ & 86 & 86 & 86 & $118-137$ & 137 & 171 & 205 \\
\hline $1250-1499$ & 137 & 137 & 137 & 171 & 205 & 205 & 205 \\
\hline $1500-1749$ & 171 & 171 & 171 & 205 & 205 & 222 & 222 \\
\hline $1750-1999$ & 171 & 171 & 205 & 222 & 222 & 222 & 222 \\
\hline $2000-2499$ & 171 & 205 & 222 & 257 & 291 & 291 & 291 \\
\hline Більше 2500 & 171 & 205 & 222 & 257 & 291 & 291 & 291 \\
\hline
\end{tabular}

Фототерапія протипоказана у випадках, коли у дитини пряма гіпербілірубінемія викликана захворюванням печінки, обтураційноюжовтяницеюабо при еритропоетиновій порфірії $[3,16]$.

Практичні аспекти проведення фототерапії

У разі задовільного клінічного стану дитини фототерапію слід проводити в умовах спільного перебування матері і дитини. Фототерапія проводиться за різними схемами. При швидкому наростанні рівня білірубіну і при критичній гіпербілірубінемії фототерапію необхідно проводити в безперервному режимі, крім періодів годування дитини (до 30 хвилин) $[9,10]$. У більш легких випадках оптимальною є тривалість до 12-18 год на добу протягом 48-72 год, з інтервалами 1-2 години для годування, проведення гігієнічних маніпуляцій. Така терапія часто проводиться в домашніх умовах, вона більш щадна і реалізується досить легко за рахунок волоконно-оптичних матрациків, ковдр.

Установка для проведення фототерапії повинна розміщуватися на відстані, прописаній у технічному паспорті апарата, не менше 5 см від кришки кувезу. При використанні стандартних установок необхідно регулярно (кожні 1,5-2 год) міняти положення дитини по відношенню до джерела світла. Дитина повинна бути повністю роздягнена. Під час проведення фототерапії очі дитини захищають окулярами або світлонепроникною пов'язкою. Немає необхідності прикривати хлопчикам мошонку світлонепроникною пов' язкою. При вираженій гіпербілірубінемії доцільно перейти до проведення інтенсивної фототерапії з використанням не менше 2 джерел світла (лампа фототерапії та фо- томатрацик). У разі відсутності кількох джерел світла для збільшення поверхні опромінення можна закрити бокові стінки ліжечка або інкубатора фольгою або білою тканиною. Інтенсивна фототерапія застосовується, якщо швидкість приросту білірубіну сироватки крові перевищує 8,5 мкмоль/л на годину, ЗБС не більше ніж на 50 мкмоль/л нижче межі для ЗПК, немає відповіді від одиночної фототерапії (ЗБС продовжує зростати або не знижується через 6 годин після початку терапії). Коли рівень ЗБС стає більш ніж на 50 мкмоль/л нижче межі для ЗПК, слід перейти на одиночну фототерапію $[7,12]$.

При відсутності протипоказань необхідно зберегти ентеральне харчування в повному обсязі.

Застосування фототерапії збільшує несуттєві втрати рідини, тому для підтримання водного балансу під час фототерапії необхідно збільшити добовий обсяг рідини на 10-20 \% (у дітей з екстремально низькою масою тіла на 40 \%) порівняно з фізіологічною нормою або на 0,5 мл/кг/год у дітей з масою тіла при народженні до 1500 г і на 1,0 мл/кг/год у дітей 3 масою тіла понад 1500 г. При неможливості випоювання дитини проводиться інфузійна терапія.

Здійснення моніторингу під час фототерапії

- Необхідно проводити оцінку клінічного стану новонародженого з жовтяницею не рідше 3 разів на добу. При цьому слід пам'ятати, що під час фототерапії відбувається швидке зникнення білірубіну зі шкіри дитини, тому забарвлення шкіри не відтворює наявні рівні гіпербілірубінемії при фототерапії протягом 24 годин після ії припинення. 
- Під час фототерапії рекомендується підтримувати температуру тіла дитини в межах $36,5-37,5^{\circ} \mathrm{C}$ i здійснювати її контроль кожні 3 години.

• Необхідно здійснювати контроль маси тіла дитини не рідше 1 разу на добу.

- На тлі фототерапії колір шкіри не може бути показником вираженості гіпербілірубінемії. Усім дітям, які отримують фототерапію, необхідно визначати рівень ЗБС крові. У разі ранньої та/або "небезпечної” жовтяниці проводити повторне визначення ЗБС через 4-6 годин після початку фототерапії, надалі залежно від результату ЗБС та клінічного стану дитини. У нормі фототерапія супроводжується зниженням ЗБС на 20-35 мкмоль/л або зниженням інтенсивності приросту нижче рівня, який вимагає ЗПК протягом 4-6 годин від початку фототерапії. У противному разі слід розглянути питання про неефективність фототерапії, що проводиться, і перейти до інтенсивної ФТ або ЗПК. У разі ускладненої “фізіологічноі”” жовтяниці або пролонгованої (затяжної) жовтяниці питання про повторне лабораторне обстеження вирішувати індивідуально в кожному випадку залежно від клінічного стану дитини.

Тривалість фототерапї

- Фототерапія у доношеного новонародженого припиняється у разі отримання результату ЗБС нижче рівня, зазначеного на рисунку 1 згідно з віком дитини і наявністю або відсутністю факторів ризику.

- Фототерапія у недоношеного новонародженого припиняється у разі отримання результату білірубіну нижче рівня, вказаного на рисунку 2 відповідно до віку дитини протягом як мінімум 12 годин і наявності або відсутності факторів ризику. Питання про проведення ЗПК вирішується у разі неефективності фототерапії, розвитку клініки гострої білірубінової енцефалопатії або у випадку підвищення рівня ЗБК до критичних рівнів (рис. 2).

Згідно з С. Езутачану рекомендовані наступні показання до припинення фототерапії (табл. 4) [5].

Таблиця 4. Показання до припинення фототерапії

\begin{tabular}{|l|l|}
\hline \multicolumn{1}{|c|}{ Маса тіла (г) при народженні } & \multicolumn{1}{c|}{ Білірубін (мкмоль/л) } \\
\hline$<1000$ & 85,5 \\
\hline $1001-1249$ & 102,6 \\
\hline $1250-1499$ & 119,7 \\
\hline $1500-1999$ & 136,8 \\
\hline $2000-2499$ & $153,9-171$ \\
\hline$>2500$ & Без гемолізу $-205,2-256,5.3$ гемолізом-205,2 \\
\hline
\end{tabular}

Рекомендується перевірити ЗБС через 12-18 годин після припинення фототерапії, при цьому мати 3 дитиною не обов' язково повинні очікувати цей час у стаціонарі $[11,17]$.

У дуже маленьких дітей ( $<1$ тижня життя) після припинення фототерапії білірубін може знову підвищуватися і часто необхідно повторно ії призначати. Введення ліпідів, якщо воно було розпочато, необхідно обмежити до 1,0 г/кг/добу, якщо рівні білірубіну в сироватці крові перевищують 136,8-171 мкмоль/л. Необхідно пам'ятати, чим менший гестаційний вік дитини, тим пізніше крива збільшення білірубіну досягає максимальної позначки, тим довше плато і тим пізніше починає знижуватися рівень білірубіну в сироватці.

Рідко в практиці зустрічаються ускладнення i побічні ефекти фототерапії: синдром "засмаглої шкіри”, синдром “бронзової дитини”, діарея, лактазна недостатність, гемоліз, опіки шкіри, збільшення несуттєвих втрат рідини, висип на шкірі, дефіцит рибофлавіну, гіпокальціємія. У разі виникнення ускладнень необхідно відмінити фототерапію. Але значущих віддалених відмінностей у розвитку новонароджених контрольної групи і дітей з використанням фототерапії виявлено не було [3, 8].

При появі ознак холестазу, про що свідчать збільшення фракції прямого білірубіну до 20-30 \% i більше, підвищення активності трансфераз печінки, лужної фосфатази, концентрації холестерину, час проведення фототерапії слід обмежити до 6-12 год/добу або зовсім відмінити, щоб уникнути розвитку синдрому “бронзової дитини”.

Висновок. Слід зазначити, що знання сучасних рекомендацій щодо проведення фототерапії у новонароджених дає практичному лікарю можливість чітких дій у виборі тактики і досягненні очікуваного терапевтичного результату. 


\section{Списоклітератури}

1. Анастасевич Л. А. Желтухи у новорожденных / Л. А. Анастасевич, Л. В. Симонова // Лечащий врач. 2010. - № 6. - С. 37-42.

2. Добрянський Д. О. Змістовий модуль 8. Найпоширеніші інфекційні хвороби новонароджених / Д. О. Добрянський, С. Л. Няньковський. - Львів : [б. в.], 2011. C. $154-157$.

3. Посібник з неонатології / [Е. Абдулаогли, С. А. Абрамс, Д. М. Адамс та ін.] ; за ред. : Д. П. Клоерті, Е. К. Ейхенвальд, Е. Р. Старк. ; пер. $з$ англ. - 6-те вид. - К. : Фенікс, 2010. C. $248-258$.

4. Про затвердження клінічного протоколу надання неонатологічної допомоги дітям “Жовтяниця новонароджених” : наказ №255 МОЗ України від 27.04. 2006 р. -К., 2006. $-32 \mathrm{c}$.

5. Практичний посібник з неонатології / за ред. С. Езутчана, Д. Добрянського ; пер. з англ. - Львів ; Детройт : [б. в.], 2002.- С. 260-261.

6. Старец Е. А. Дифференциальная диагностика и ведение неонатальных желтух: современное состояние проблемы / Е. А. Старец, Н. А. Малиновская, Н. В. Мовлянова // Здоровье ребенка. -2012. -№ 3 (38). - С. 134-137.

7. Шабалов Н. П. Неонатология : учеб. пособие : в 2 т. / Н. П. Шабалов - 5-е изд., испр. и доп. - М. : МЕД прессинформ, 2009.- Т. 2.-С. 542-555.

8. Phototherapy causes DNA damage in peripheral mononuclear leukocytes in term infants / A. Aycicek, A. Kocyigit, O. Erel [et al.] // Jornal de Pediatria. - 2008. Vol. 84(2).-P. 141-146.

9. Transepidermal water loss and cerebral hemodynamics in preterm infants: conventional versus LED phototherapy / G. Bertini, S. Perugi, S. Elia [et al.] // European Journal of Pediatrics. -2008. -Vol. 167 (1). - P. 37-42.

10. Efficacy of phototherapy for neonatal jaundice is increased by the use of low-cost white reflecting curtains / S. Djokomuljanto, B. S. Quah, Y. Surini [et al.] // Archives of
Disease in Childhood Fetal and Neonatal Edition. - 2006. Vol.91(6).-P.439-442.

11. Gartner L. Hyperbilirubinemia and breastfeeding / L. Gartner // Textbook on Lactation / Hale T.W., Hartmann P.E., eds. - Pharmasoft Publishing, Amarillo, TX, 2007.

12. Guidelines for detection, management and prevention of hyperbilirubinemia in term and late preterm newborn infants (35 or more weeks' gestation) Canadian Paediatric Society // Paediatrics and Child Health. -2007.--Vol. 12 (Suppl.B).-P. 1-24.

13. Kaplan M. Israel guidelines for the management of neonatal hyperbilirubinemia and prevention of kernicterus / M. Kaplan, P. Merlob, R. Regev // Journal of Perinatology. 2008. - Vol.28(6).-P.389-397.

14. Prognostic value of direct bilirubin in neonatal hyperbilirubinemia / M. Mamtani,A. Patel, R. Renge [et al.] // Indian Journal of Pediatrics. - 2007. - Vol. 74 (9). - P. 819-822.

15. National Institute for Health and Clinical Excellence. The guidelines manual. - London : National Institute for Health and Clinical Excellence, 2009.

16. Range of UK practice regarding thresholds for phototherapy and exchange transfusion in neonatal hyperbilirubinaemia/J. M. Rennie,A. Seghal,A. De [et al.]// Archives of Disease in Childhood Fetal and Neonatal Edition. -2009.-Vol.94(5):F323-F327. doi:10.1136/adc.2008.147686

17. Is visual assessment of jaundice reliable as a screening tool to detect significant neonatal hyperbilirubinemia? / A. Riskin,A. Tamir, A. Kugelman [et al.] // Journal of Pediatrics. -2008. - Vol. 152 (6). - P. 782-787.

18. Which phototherapy system is most effective in lowering serum bilirubin in very preterm infants? / C. Romagnoli, E. Zecca, P. Papacci [et al.] // Fetal Diagnosis and Therapy. 2006. - Vol. 21 (2). - P. 204-209.

19. Watchko J. F. Enduring controversies in the management of hyperbilirubinemia in preterm neonates / J. F. Watchko, M. J. Maisels // Seminars in Fetal \& Neonatal Medicine. 2010. -Vol. 15(3). - P. 136-140. 